\title{
Identifikasi Tipologi berdasarkan Karakteristik Sempadan Sungai di Kecamatan Semampir
}

\author{
Della Safira dan Ema Umilia \\ Departemen Perencanaan Wilayah dan Kota, Fakultas Teknik Sipil dan Perencanaan, Institut Teknologi Sepuluh \\ Nopember (ITS) \\ e-mail:ema_umilia@urplan.its.ac.id
}

\begin{abstract}
Abstrak-Ruang Terbuka Hijau merupakan elemen yang keberadaannya penting dan perlu dipertahankan. Namun demikian, Kecamatan Semampir masih belum dapat mengimplementasikan jumlah RTH yang ideal. Hal ini disebabkan minimnya lahan yang tersedia. Oleh sebab itu diperlukan alternatif dalam peningkatan RTH yaitu dengan pemanfaatan sempadan sungai yang terdapat wilayah tersebut. Sungai tersebut adalah Sungai Kalimas dan Sungai Kali Pegirian. Dengan demikian penentuan tipologi sempadan sungai berdasarkan karakteristiknya berguna untuk memberikan gambaran terkait dari kondisi sempadan sungai tersebut. Dengan metode skoring, penelitian ini menghasilkan tipologi yang terdapat pada sempadan sungai di Kecamatan Semampir. Hasil analisis dari penelitian ini menunjukan bahwa terdapat 69 segmen yang ada pada sempadan sungai di Kecamatan Semampir dan terdapat 3 tipologi yang menggambarkan kondisi dari sempadan sungai di Kecamatan Semampir yaitu Tipologi I dengan keadaan baik, Tipologi II dengan keadaan sedang dan Tipologi III dengan keadaan buruk.
\end{abstract}

Kata Kunci-Sempadan, Sungai, RTH, Tipologi Wilayah.

\section{PENDAHULUAN}

$\mathrm{S}$ EBUAH kota setidaknya memiliki 30\% ruang terbuka hijau dengan proporsi $10 \%$ milik privat dan $20 \%$ milik publik apabila ditinjau dari luasan wilayahnya [1]. Sedangkan ditinjau dari jumlah penduduknya, standar penyediaan diatur dengan mengalikan antara jumlah penduduk yang dilayani dengan standar luas RTH per kapita sesuai peraturan yang berlaku. Luas RTH di Surabaya pada tahun 2013 adalah sebesar $23,82 \%$ sehingga memiliki surplus sebanyak $3,82 \%$. Namun ditinjau dari pesebaran di tiap bagian wilayah Surabaya, tidak semua kawasan telah memiliki luasan RTH yang cukup. Surabaya Barat memiliki luas RTH sebesar 23,35\%, Surabaya Pusat memiliki luas RTH sebesar $8,86 \%$, Surabaya Selatan memiliki luas RTH sebesar $28,44 \%$, Surabaya Timur memiliki luas RTH sebesar 24,16\%, dan Surabaya Utara memiliki luas RTH sebesar 17,5\% jika dibandingkan dengan luas wilayahnya masing - masing [2].

Kecamatan Semampir merupakan salah satu kecamatan yang ada di Surabaya Utara dan memiliki permasalahan terkait penyediaan RTH [3]. Jumlah RTH di wilatah tersebut sangat terbatasdan kenaikan penduduk yang terus menerus menyebabkan kebutuhan akan lahan terus meningkat sehingga semakin minim pula lahan yang dialokasikan untuk RTH. Selain itu, keadaan sempadan sungai di Kecamatan Semampir padat, kumuh dan banyak dijumpai bangunan yang mepet dengan jalan. Terdapat pula sampah di sekitar sungai sehingga sempadan sungai yang ada perlu direvitalisasi dengan cara penanaman tanaman untuk menghilangkan kesan kumuh [3].

Di sepanjang Sungai Kali Pegirian di Kecamatan Semampir terdapat permukiman liar yang berupa bangunan semi permanen sehingga semakin terbatasnya ruang terbuka untuk penyegaran [4]. Titik utama pemukiman kumuh yang ada diantaranya pada Kelurahan Wonokusumo dan Kelurahan Ujung dengan tingkat kekumuhan ringan dan sedang [5]. Sedangkan di sepanjang Sungai Kalimas di Kecamatan Semampir, merupakan bekas pasar petekan yang sudah di bongkar sehingga berpotensi untuk menjadi ruang terbuka hijau [6].

Dengan demikian, salah satu alternatif dalam peningkatan ruang terbuka hijau di Kecamatan Semampir adalah memanfaatkan kawasan sempadan sungai. Dalam menentukan konsep dan program terkait alternatif peningkatan RTH di sempadan sungai, diperlukan identifikasi terkait karakteristik sempadan sungai yang ada di Kecamatan Semampir sehingga arahan yang akan dibuat sesuai dengan kondisi sempadan sungai yang ada.

Penelitian ini bertujuan untuk mengidentifikasi tipologi di Kecamatan Semampir berdasarkan karaktersitik sempadan sungai yang ada. Tipologi yang ada berguna untuk memberikan gambaran terkait kondisi fisik dan non fisik di sempada sungai di Kecamatan Semampir.

\section{METODE PENELITIAN}

\section{A. Jenis dan pendekatan Penelitian}

Pendekatan yang digunakan dalam penelitian ini adalah pendekatan rasionalistik. Jenis penelitian ini merupakan penelitian kualitatif dengan metode deskriptif

\section{B. Variabel Penelitian}

Variabel pada penelitian ini diantaranya lebar ruang terbuka, kondisi fisik bangunan, kesan lingkungan, jenis vegetasi, penggunaan lahan, intensitas penggunaan lahan, dan kepadatan penduduk

\section{Identifikasi Karakteristik Sempadan Sungai}

Dalam mengidentifikasi karakteristik sempadan sungai di Kecamatan Semampir, dilakukan observasi lapangan. Hasil segmentasi tiap sungai didapat dari membagi daerah sempadan berdasarkan blok. Dasar penetapan segmen berdasarkan blok karena tiap blok dibatasi dengan jalan dan batas tersebut diperkirakan tidak akan berubah / hilang pada masa yang akan datang. Setelah dilakukan pembagian segmentasi sempadan sungai, dilakukan analisis skoring pada tiap tiap variabel yang ada. Teknik skoring merupakan teknik dalam menganalisis data 
dengan memberikan nilai terhadap keadaan yang ada berdasarkan kriteria-kriteria yang ditentukan. Nilai yang ada pada tiap variabel dijumlah dan menghasilkan skor pada tiap segmen.

Identifikasi Tipologi Sempadan Sungai di Kecamatan Semampir

Hasil skoring dari variabel yang ada akan diakumulasikan dengan menjumlah masing- masing bobot yang telah didapatkan. Setelah dilakukan akumulasi, segmen yang ada akan dikelompokkan menjadi 3 kategori. Kategori I merupakan segmen dengan keadaan paling baik. Kategori II merupakan segmen yang memiliki keadaan sedang. Kategori III merupakan segmen yang memiliki keadaan paling buruk. Pembagian interval dihitung dengan cara

$$
\text { Interval }=\frac{\text { total nilai maksimal }- \text { total nilai minimal }}{3}
$$

\section{HASIL DAN PEMBAHASAN}

\section{A. Identifikasi Karakteristik Sempadan Sungai}

Terdapat 2 sungai di Kecamatan Semampir yaitu Sungai Kali Pegirian dan Sungai Kalimas. Sungai Kali Pegirian membentang dari Kelurahan Ampel, Sidotopo, Pegirian, Ujung, dan Wonokusumo sedangkan Sungai Kalimas membentang di Kelurahan Ujung. Dari hasil observasi lapangan, terdapat 65 blok di sepanjang sungai Kali Pegirian dan 4 blok di sepanjang Sungai Kalimas yang ada di Kecamatan Semampir. Dengan demikian terdapat 65 segmen di Sungai Kali Pegirian dan 4 segmen di Sungai Kalimas di Kecamatan Semampir.

Segmen 1-26 terletak pada Kelurahan Ampel dan Kelurahan Sidotopo. Penggunaan lahan pada segmen ini merupakan perdagangan jasa dan pergudangan. Keadaan sempadan sungai pada segmen ini sudah baik ditandai dengan tanaman yang ditanam sudah terawat dengan baik. Selain itu jarak sempadan sungai lebih dari 10 meter menandakan bahwa kondisi sempadan sungai yang ada sudah sesuai dan tidak kumuh. Berikut ini merupakan peta dari segmen 1-26.

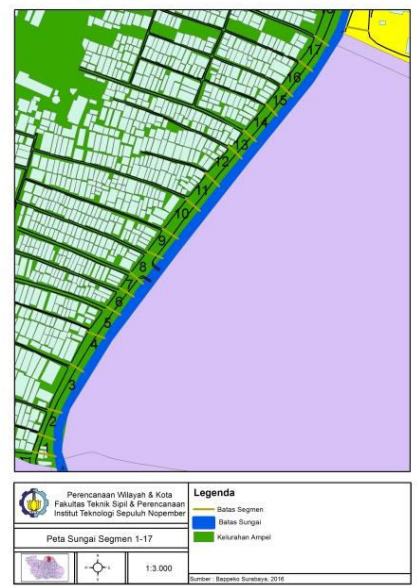

Gambar 1. Peta Segmen 1-18.

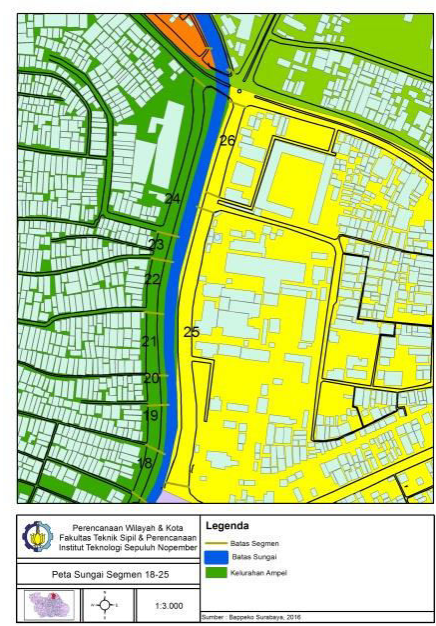

Gambar 2. Peta Segmen 19-26.

Segmen 27 - 40 dan 49-54 merupakan bagian dari Sungai Kali Pegirian yang terletak pada Kelurahan Ujung dan Kelurahan Pegirian. Penggunaan lahan yang dominan pada segmen ini adalah permukiman. Segmen ini memiliki kepadatan bangunan yang cukup tinggi, yaitu berkisar 60\% sampai $80 \%$. Jarak sempadan sungai yang berkisar anatara 5-7 meter dan beberapa bangunan semi permanen menyebabkan kesan kumuh pada segmen ini. Berikut ini merupakan peta dari segmen 27-40 dan 49-54.

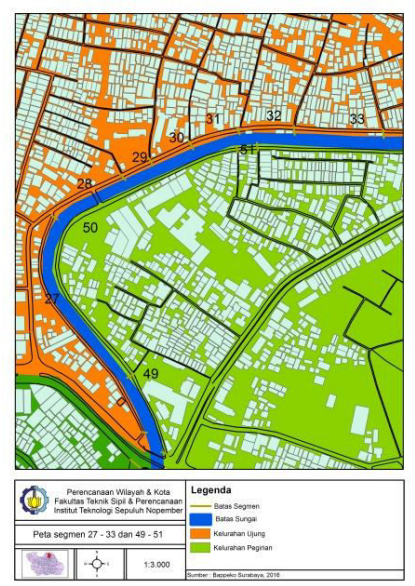

Gambar 3. Peta segmen 27-33, dan 49-51.

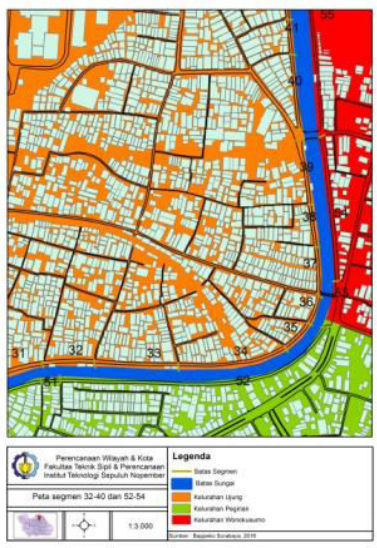

Gambar 4. Peta Segmen 32-40 dan 52-54. 
Segmen 40-47 dan 55-60 merupakan bagian dari Sungai Kali Pegirian yang terletak pada Kelurahan Ujung dan Kelurahan Wonokusumo. Penggunaan lahan yang dominan pada segmen ini adalah permukiman serta industri dan pergudangan. Segmen ini memiliki kepadatan bangunan berkisar $40 \%$ sampai $80 \%$. Jarak sempadan sungai berkisar anatara 5-7 meter. Bangunan yang ada pada segmen ini sudah permanen . sempadan sungai yang ada banyak yang kosong dan tidak ditanami tumbuhan sehingga berpotensi untuk dikembangkan sebagai ruang terbuka hijau. Berikut ini merupakan peta dari segmen 40-47 dan 55-60.

Segmen 48 dan 61 - 65 merupakan bagian dari Sungai Kali Pegirian yang terletak pada Kelurahan Ujung dan Kelurahan
Wonokusumo. Khusus pada segmen 48 memiliki penggunaan lahan kawasan militer. Sempadan sungai pada segmen 48 hanya terdapat tanaman liar sehingga dapat berpotensi untuk dikembangkan sebagai ruang terbuka hijau. Pada segmen 61-65, penggunaan lahan yang ada adalah permukiman dan beberapa kawasan industri. Jarak sempadan sungai berkisar antara 5-7 meter. Sempadan sungai yang ada banyak digunakan sebagai tempat parkir, tempat menjemur pakaian dan tempat meletakkan barang barang yang berukuran besar. Berikut ini merupakan peta dari segmen 48 dan $61-65$.

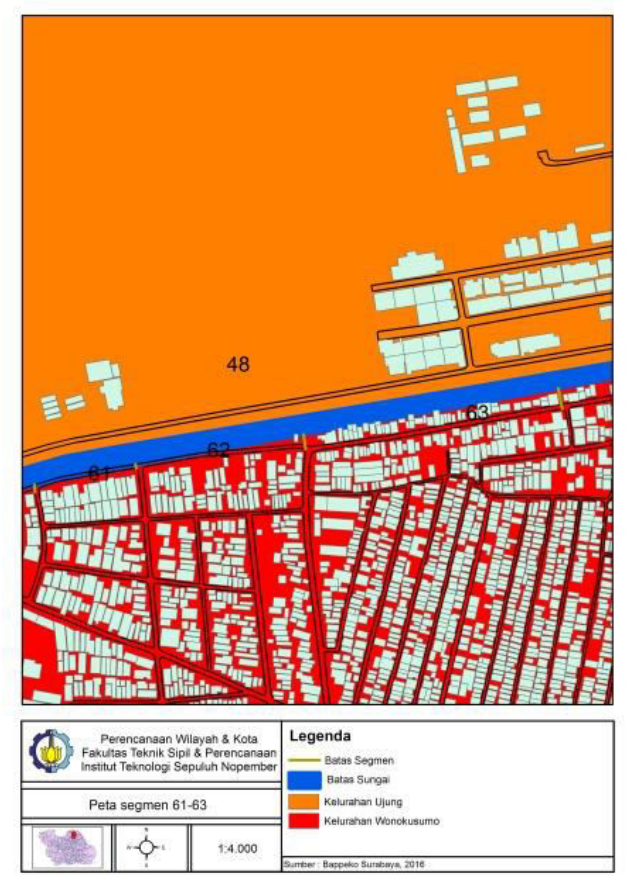

Gambar 7. Peta Segmen 48 dan 61-63.
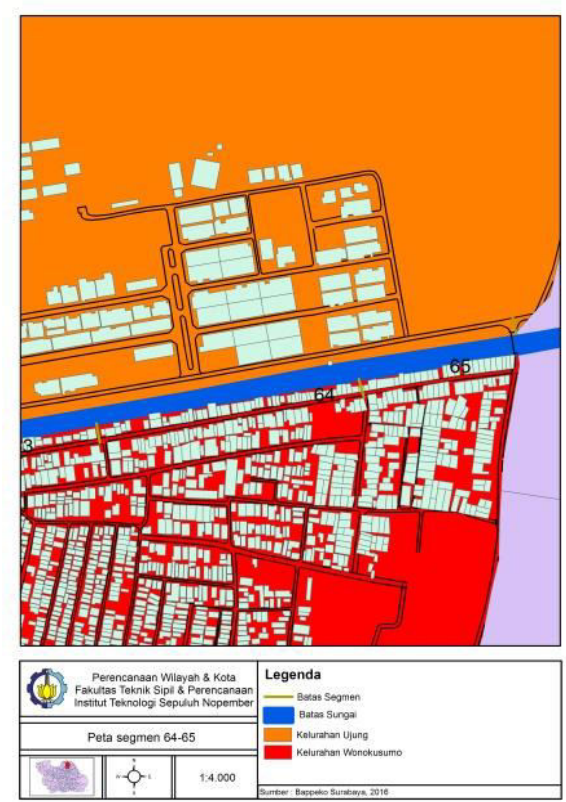

Gambar 8. Peta Segmen 63-65. 
Segmen 66-69 merupakan bagian dari Sungai Kalimas yang terletak di Kelurahan Ujung. Sempadan sungai pada segmen ini terletak pada kawasan militer dengan penggunaan lahan perkantoran militer dan instalansi bandaran. Jarak sempadan sungai yang lebih dari 10 meter dan bangunan yang ada merupakan bangunan permanen sehingga tidak menghasilkan kesan kumuh. Sempadan sungai pada segmen ini sudah terawat dengan baik ditandai dengan adanya tanaman trembesi di sepanjang area sempadan sungai. Berikut ini merupakan peta dari segmen $66-69$.

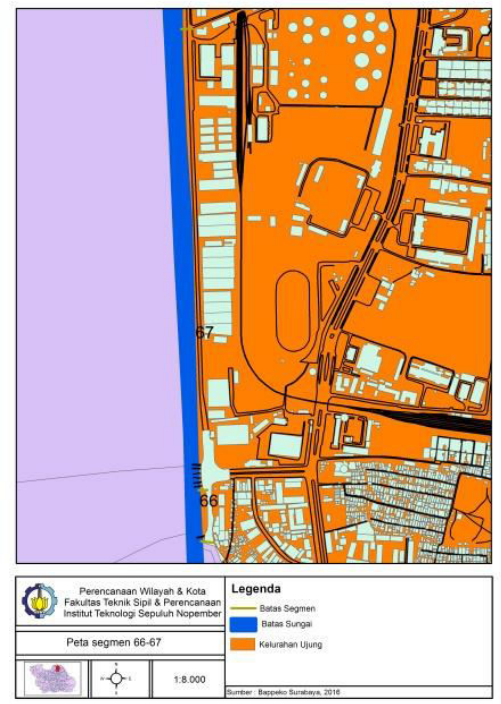

Gambar 9. Peta Segmen 66-67

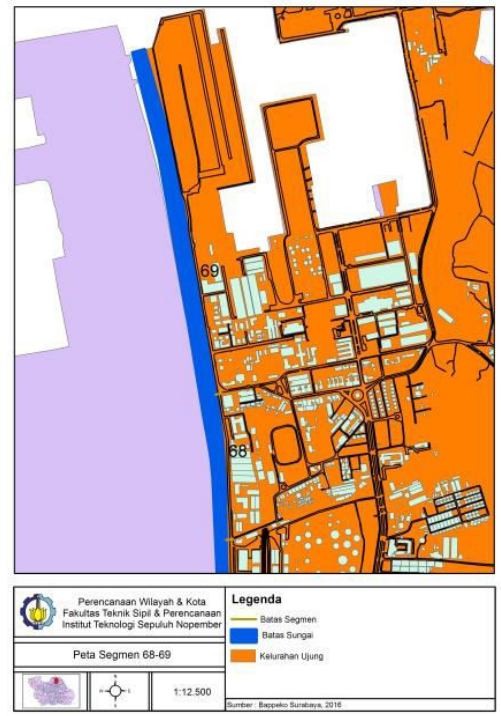

Gambar 10. Peta Segmen 68-69

Karakteristik sempadan sungai di Kecamatan Semampir dibagi menjadi beberapa variabel amatan lebar ruang terbuka, kondisi fisik bangunan, kesan lingkungan, jenis vegetasi, penggunaan lahan, intensitas penggunaan lahan, dan kepadatan penduduk. Kondisi yang terburuk akan diberikan nilai 1 dan kondisi yang terbaik akan diberi skor 4. Berikut ini merupakan hasil dan skor dari tiap tiap segmen.
Tabel 1.

Skor pada tiap Segmen Sempadan Sungai di Kecamatan Semampir

\begin{tabular}{rrrrrr}
\hline \hline Segmen & Skor & Segmen & Skor & Segmen & Skor \\
\hline 1 & 14 & 24 & 15 & 47 & 15 \\
2 & 15 & 25 & 19 & 48 & 14 \\
3 & 15 & 26 & 19 & 49 & 12 \\
4 & 15 & 27 & 17 & 50 & 13 \\
5 & 16 & 28 & 15 & 51 & 13 \\
6 & 14 & 29 & 16 & 52 & 13 \\
7 & 15 & 30 & 13 & 53 & 14 \\
8 & 15 & 31 & 12 & 54 & 11 \\
9 & 15 & 32 & 13 & 55 & 10 \\
10 & 15 & 33 & 12 & 56 & 11 \\
11 & 14 & 34 & 12 & 57 & 12 \\
12 & 15 & 35 & 14 & 58 & 12 \\
13 & 14 & 36 & 15 & 59 & 12 \\
14 & 15 & 37 & 15 & 60 & 13 \\
15 & 14 & 38 & 11 & 61 & 11 \\
16 & 14 & 39 & 12 & 62 & 13 \\
17 & 16 & 40 & 15 & 63 & 9 \\
18 & 16 & 41 & 13 & 64 & 12 \\
19 & 15 & 42 & 13 & 65 & 8 \\
20 & 14 & 43 & 14 & 66 & 13 \\
21 & 13 & 44 & 13 & 67 & 17 \\
22 & 14 & 45 & 12 & 68 & 17 \\
23 & 15 & 46 & 15 & & \\
\hline \hline \hline 2 & 15 & & & \\
\hline
\end{tabular}

Sumber : Hasil Analisis, 2016

\section{B. Identifikasi Tipologi Sempadan Sungai di Kecamatan Semampir}

Penentuan interval pada penelitian ini dilakukan dengan cara mengurangi nilai maksimal yang mungkin dihasilkan dengan nilai minimal yang mungkin dihasilkan dan dibagi menjadi 3 . Nilai maksimal yang dapat dihasilkan pada skoring kali ini adalah 19 dan nilai minimal yang dapat dihasilkan adalah 7 . Sehingga apabila dimasukkan kedalam rumus, hasil yang didapatkan adalah sebagai berikut.

$$
\begin{aligned}
& \text { Interval }=\frac{\text { Nilai maksimal-nilai minimal }}{\text { Interval }=\frac{19-7}{a}=4}
\end{aligned}
$$

Sehingga didapatkan interval sebagai berikut :

Tabel 2.

Pembagian Interval

\begin{tabular}{ccclcc}
\hline \hline No & Tipologi & Interval Skoring & \multicolumn{3}{c}{ Keterangan } \\
\hline 1 & Tipologi I & $15-19$ & $\begin{array}{l}\text { Keadaan sempadan } \\
\text { yang baik }\end{array}$ & sungai \\
2 & Tipologi II & $11-14,9$ & $\begin{array}{l}\text { Keadaan sempadan } \\
\text { sedang }\end{array}$ & sungai \\
3 & Tipologi III & $7-10,9$ & $\begin{array}{l}\text { Keadaan } \\
\text { buruk }\end{array}$ & sempadan & sungai \\
\hline \hline
\end{tabular}

Sumber : Hasil Analisis, 2017

Dengan demikian, dari skor yang telah didapatkan maka didapatkan pula tipologi pada segmen yang ada. Berikut ini merupakan pembagian tipologi beserta segmen yang ada pada sempadan sungai di Kecamatan Semampir. 
Tipologi Sempadan Sungai

\begin{tabular}{lll}
\hline \hline No & Tipologi & Segmen \\
1 & Tipologi I & $2,3,4,5,6,7,89,10,12,14,17$, \\
& & $18,19,23,24,25,26,27,28,29,36$ \\
& & $37,40,46,47,67,68$ \\
2 & Tipologi II & $1,11,13,15,16,20,21,22,30,31$, \\
& & $32,33,34,35,39,41,42,43,44,45$, \\
& & $48,49,50,51,52,53,57,58,59,60$, \\
& & $62,64,66$ \\
3 & Tipologi III & $38,54,55,56,61,63,65$ \\
\hline \hline
\end{tabular}

Sumber : Hasil Analisis, 2017

\section{KESIMPULAN}

Kesimpulan dari hasil dan pembahasan adalah sebagai berikut:

1. Terdapat 69 segmen pada pembagian sempadan sungai di Kecamatan Semampir. Sempadan Sungai Kali Pegirian memiliki 65 segmen dan sempdan Sungai Kalimas memiliki 4 segmen.
2. Terdapat 3 tipologi pada pembagian sempadan sungai di Kecamatan Semampir berdasarkan karakteristiknya yaitu Tipologi I dengan keadaan sempadan sungai yang baik, Tipologi II dengan keadaan sempadan sungai sedang, Tipologi III dengan keadaan sempadan sungai buruk.

3. Tipologi I berjumlah 28 segmen, Tipologi II berjumlah 33 dan Tipologi III berjumlah 7 segmen.

\section{DAFTAR PUSTAKA}

[1] Badan Koordinasi Tata Ruang Nasional, "Undang-Undang Republik Indonesia Nomor 26. Tahun 2007 tentang Penataan Ruang," 2007.

[2] E. . Alfatikh, "Evaluasi Pengembangan Wilayah Ruang Terbuka Hijau Sebagai Daya DUkung Lingkungan Kota Surabaya," 2013.

[3] Anonymous, "RDTRK UP Tanjung Perak Tahun 2010-2020."

[4] G. Y. Nisah, "Pemukiman Liar di Surabaya Tahun 1970-2000," Publika Budaya Vol, vol. 2, pp. 58-68, 2014.

[5] Anonymous, "Laporan Data Dasar RP4D Kota Surabaya."

[6] Pemerintah Kota Surabaya, "Dokumentasi Kawasan Lingkungan Sungai Kalimas Surabaya," 2008. 